8 Report by Analytical Methods Committee, Analyst 88, 415 (1963).

${ }^{9}$ I. A. Favorskaya and V. I. Lukina, Vest. Leningr. Univ. Ser. Fiz. i Khim. 2, 148 (1961).

10 W. Kirsten, Mikrochim. Acta [Wien] 1960, 272.

11 D. C. White, Mikrochim. Acta [Wien] 1961, 449.

12 N.G.Gaylord, Reduction with complex metal hydrides. New York: Interscience. 1956. p. 18.

is N.U. Sokolova, V.A. Orestova, and N.A. Nikolajeva, Zhur. Anal. Khim. 16, 442 (1959).

${ }_{14}$ F. W. Cheng, Microchem. J. 3, 537 (1959).

${ }_{15}$ D. A. Lyttle, E. H.Jensen, and W. A. Struck, Analyt. Chemistry 24, 1843 (1952).

\title{
Mitteilungen aus chemischen Gesellschaften
}

\section{A. A. Benedetti-Pichler Memorial A ward}

The American Microchemical Society has created a fund to commemorate the work of the late Dr. A.A. Benedetti-Pichler. The award will be made to an individual who has made outstanding contributions to the practice or teaching of microtechniques. The award will be given at regular intervals with the understanding that the recipient will give a lecture at a gathering of analytical chemists covering the field for which the award has been designed. A mutually agreeable location and occasion will be decided upon with the recipient.

Nominations are now being solicited and must be in the hands of the committee by May 1, 1969. A letter of 300 words or less, giving the name and address of the nominee and citing, in general, his work may be sent to the Chairman of the 1969 Committee, Mr. Erik R. Hoffmann, Ethicon, Ine., P. O. Box 15L, Somerville, New Jersey 08876, U. S. A.

\section{Conference on Electron Microprobe Analysis}

The Electron Probe Analysis Society of America will hold the Fourth National Conference on Electron Microprobe Analysis July 16-18, 1969 at the Huntington-Sheraton Hotel, Pasadena, California. The General chairman of the meeting is Prof. D. B. Wittry of the University of Southern California. Final date for submission of 500-900 word extended abstracts will be April 15, 1969. For further information contact Dr. A. A. Chodos, Geology Dept., California Institute of Technology, Pasadena, Calif. 91109, U. S. A.

Herausgeber, Eigentümer und Verleger: Springer-Verlag, Mölkerbastei 5, A-1010 Wien. - Für den Textteil verantwortlich: Prof. Dr. Michael Karl Zacherl. Chimanistraße 21. A-1190 Wien. - Für den Anzeigenteil verantwortlich: Alois Hailwax, Paracelsusgasse 8, A-1030 Wien. - Druek: Manzsche Buchdruckerei, Lustkandigasse 52, A-1090 Wien 